\title{
Multiple Effects of Bracken Fern under in vivo and in vitro Conditions
}

\author{
Motahhareh Tourchi-Roudsari
}

\begin{abstract}
Several toxic substances have been detected in plants which are responsible for animal and human diseases. Bracken fern (Pteridium aquilinum) is one example, widely distributed in many parts of the world. It is known to cause cancer in humans and other animals. In fact, man can be directly or indirectly exposed to the danger by consuming fern, contaminated water, milk, meat, and spore inhalation. Experimental studies have shown an association between bracken exposure and gastric cancer, and research has shown genotoxic and cytotoxic effects in vitro. This paper describes and reviews toxic, carcinogenic, genotoxic/cytotoxic, and immunomodulatory effects of bracken and included possible toxic agents. The chemistry of Ptaquiloside (PT) reactions is emphasized, along with bracken problems in livestock, possible pathways of exposure in man, and control for human health.
\end{abstract}

Keywords: Bracken fern - Ptaquiloside - DNA damage - cancer - induction

Asian Pac J Cancer Prev, 15 (18), 7505-7513

\section{Introduction}

Bracken (Pteridium aquilinum) is a plant that is spread all over the world, especially in acidic forest soils, warm dark areas of both torrid, subtorrid zones, woods, and road sides (Marrs and Watt, 2006; Xu et al., 2009). Some human populations, such as Japan, Ouro Preto area in Brazil, Canada, and China, consume bracken crosiers as a nourishing and delicious food (Hirono, 1993; Chen et al., 2008; Li et al., 2008; Hojo-Souza et al., 2010). It is very nutrient-dense and a good source of protein, carbohydrates, fat, vitamins, carotenoids, and trace minerals (Li et al., 2008).

In addition, bracken has numeral effects including immunomodulatory, anticancer, low blood pressure, antiviral, anti-bacterial, anti-inflammatory, and antioxidant effects. (Potter et al., 2000; Xu et al., 2009; Wang et al., 2010; Xia et al., 2010; Wang and Wu., 2013). This plant is native to the Gilan province, Mazandaran and Golestan in Iran (Khoshravesh et al., 2009; Tourchi Rodsari et al., 2012). Furthermore, the distribution of bracken-fern is noticeable in some areas such as United Kingdom (Vetter, 2009), south and Central America, South-East Asia, and Oceania (Gil da Costa et al., 2012). Unlike other ferns (Burrows and Tyrl, 2001), it does not need a lot of water and can grow in variable conditions easily.

Many scientists focused their studies on this plant because of its probable effects on human health and animal. So researches began on this interesting plant mass (Wilson et al., 1998). Long-term exposure to bracken causes similar effects of ionizing radiation (Evans et al., 1968).
Ion-causing compounds are related to the production of bracken radicals (Povirk et al., 2006). These are the initial effectors of DNA lesion and chromosomal aberrations. Epidemiological studies have shown association between the occurrence of neoplasms in humans and ingestion of bracken leaves (Shahin et al., 1999; Alonso-Almelot and Avendano 2001; 2002), the consumption of milk from cows fed bracken fern (Alonso-Amelot et al., 1996; Cot, 2008), or the consumption of contaminated water with compounds of ferns (Rasmussen et al., 2003).

The main toxic agent in bracken is Ptaquiloside, a nor-sesquiterpene glycoside that is responsible for carcinogenic and toxic syndrome of the fern (Yamada et al., 2007). The highest concentration of PT was found in leaves and young unfolding fronds. The mutagenicity, clastogenicity, teratogenicity and carcinogenicity have been demonstrated. Some epidemiological evidences have shown higher risk of gastric and/or esophageal cancer in people who consume bracken crosiers; people who consume milk of cows that are grazing in brackeninfested areas (Yamada et al., 2007; Cot, 2008; Fletcher et al., 2011). PT has been found in milk of bracken-fed cattle through experimental tests.

Studies have revealed other toxic compounds existing in bracken fern, which depend on ptaquiloside (Castillo et al., 1998) despite having lower concentrations (Freitas et al., 2001). Furthermore, studies proved that bracken extract can cause cell death through DNA damaging by activating apoptosis mechanism. (Siman et al., 2000; Campos-da-Paz et al., 2008; Pereira et al., 2009; Tourchi Roudsari et al., 2012) It may also induce inhibition of 
cell growth via cell cycle arrest on cancer cells in vitro (Tourchi Roudsari et al., 2012)..

\section{Toxicity of Bracken Fern}

The inductions of toxic syndromes by ingestion of bracken fern are different in horses, cattle, and sheep (Evans et al., 1982). Ingestion of bracken fern by horses causes thiamine deficiency. In fact, each part of bracken containing thiaminase type $\mathrm{I}$ is able to split the thiamine molecule. The presence of heat-stable anti-thiamin factor has been reported in bracken that may be involved in the formation of a lack. in addition, the presence of thiaminase has been proved. Most features of toxicity are depressed bone marrow activity, appearance of severe leucopenia, particularly granulocyte, thrombocytopenia, the hemorrhagic syndrome, and hematuria in cattle (PerezAlenza et al., 2006; Di Loria et al., 2012). However, toxicity is directly influenced by quantity, the time of year and the part of the plant is important too (SameckaCymerman et al., 2009).

\section{Genotoxic/Cytotoxic Effects of Bracken Fern}

Many studies have proved that BF extract induces genetic instabilities and DNA damage response in cells in vitro condition. Lately, researches showed that bracken extract and PT cause DNA strand breaks in gastric cells in vitro. In fact, it associates with a decrease of cell viability; induction of late apoptotic, and necrotic cells (Gomes et al., 2012). Furthermore, bracken extract induces DNA damage and its apoptosis at high concentrations. It also may cause cell cycle arrest at mild concentrations. In fact, we showed that bracken extract can have both genotoxic and cytotoxic effect in vitro (Tourchi Roudsari et al., 2012).

In agreement with our results, a previous study reported the induction of apoptosis and cytotoxicity by BF extracts in human epithelial cells through DNA damage (Pereira et al., 2009). In addition, bracken spore causes DNA strand break in human premyeloid leukemia cells in vitro (Siman et al., 2000). Other studies have shown that bracken fern extracts induce chromosomal aberrations in mammalian cells (Almeida Santos et al., 2006). Many experiments have been done on bracken fern extracts that all of them show genotoxicity/cytotoxicity of bracken in vitro (Campos-da-Paz et al., 2008; Gil da Costa et al., 2012). According to studies, scientists clearly showed that PT can be the main agent for inducing DNA damage (Pereira et al., 2009; Gomes et al., 2012). Besides, initial studies proved that ptaquiloside-DNA interactions directly lead to spontaneous deamination and DNA strand breakage (Kushida et al., 1994). However, observers showed that DNA damage occurs by different compounds in bracken extract that they are not only PT and its derivatives but also other DNA damaging compounds (Yamada et al., 2007).

Studies with evaluation of p53 gene expression have showed that DNA damage occurs during the first hours of exposure to Gastric epithelial cells. Exposure to PT leads to deregulation of some genes expression that may cause two different responses: cell cycle arrest and DNA repair
(Gomes et al., 2012).

\section{Carcinogenic Properties of Bracken Fern}

Lately, results have showed that bracken extract causes cancer in mice (Gomes et al., 2012). Progression of multiple ilea adenocarcinomas was seen among rats with a diet rich in bracken fern (Evans and Mason, 1965). At the same time, occurrence of intestinal and urinary bladder tumors was induced in such rats. Then, animals were died or killed (Pamukcu and Price, 1969). Investigations showed adenomatous polyps and adenocarcinomas progress predominantly in ileum. Hirono and co-workers proposed that highest frequency of urinary bladder tumors will be developed if small amounts of carcinogens are given over long period of times (Hirono et al., 1970). In fact, many studies have been intensively done on brackenassociated bladder tumors morphologically, especially in cattle (Carvalho et al., 2006). Some studies sought a molecular approach in rats (Freitas et al., 2002) and cows (Corteggio et al., 2010; Roperto et al., 2010; Corteggio et al., 2011).

Recent studies have showed that ptaquiloside, the most imperative carcinogen agent in bracken, can induce malignant transformation in mice and supply an indepth characterization of lymphoproliferative damages. Furthermore, experiments have proved that urinary bladder is a target organ in mice as well as in other animal species (Gil da Costa et al., 2011). Observations showed that young leaves of bracken in crosier stage of growth are consumed as food by human; However, when a diet mentioned powdered young bracken fern in a ratio of 1 part by weight of bracken to 2 parts of basal diet were given to rats for 4 month, all of the rats which survived for more than 7 months from the start time of the experiment had ilea tumors. In Japan, young bracken fern is usually consumed as food by humans after its astringent taste has been eliminated according to one of the following treatments: 1) Fresh bracken fern is submerged in boiling water containing wood ash or sodium bicarbonate, and then spiced; occasionally, it is only boiled before eating. 2) Fresh bracken is soured in salt and submerged in boiling water before eating (Cheeke, 1989). The carcinogenic activity in rats that consumed a processed brackencontaining diet as a human food was investigated (Hirono et al., 1972). Tumor frequency in rats with an unprocessed bracken-containing diet was $78.5 \%$; in contrast, in rats fed with a diet containing processed bracken treated with wood ash, sodium bicarbonate, and $\mathrm{NaCl}$, tumor incidence was 25,10 , and $4.7 \%$ respectively. Findings show that the treatment markedly reduces the carcinogenic activity of bracken fern though weak carcinogenic activity was retained in bracken after treatment.

Scientists are investigating to find out the relationship between the stage of maturation of bracken and carcinogenic effects. The carcinogenicity of mature bracken was compared with young one. According to experiments, mature bracken fern had strong carcinogenic activity; however, it was weaker than immature one. (Cheeke, 1989). Furthermore, Hirono and co-workers showed development of papilomas of tongue, pharynx, 
esophagus, forestomach, and squamous cell carcinoma of pharynx in rats fed a diet containing bracken (Hirono et al., 1982).

\section{Bracken Cancer Model}

Scientists showed that DNA damage occurs at early stages of carcinogenicity, leading to oncogenic mutations. They also reported an increase in cell proliferation happening in gastric mucosa of bracken treated mice (Gomes et al., 2012). Moreover, DNA adducts and HRAS mutations are known in mammary glands of rats which receive distinctive doses of bracken dienone-a carcinogenic compound- (Shahin et al., 1998; Gomes et al., 2012). Because p53 gene usually suppresses tumors in human (Petitjean et al., 2007), researchers evaluated mutations in exons 2-4 in treated mice. The results showed the presence of BF-induced frameshift mutations in intron 2 regions (Gomes et al., 2012). The alterations in intron 2 are also able to modulate the splicing process and then influence on p53 expression (Gomes et al., 2012). In agreement, Previous studies proved p53 gene mutations induced by bracken fern (Shahin et al., 1998; Freitas et al., 2002). Researchers also suggested a model for bracken carcinogenesis (Shahin et al., 1999). Based on this model, bracken induces carcinogenesis in two distinctive levels of both cellular and molecular in vivo (Shahin et al., 1999). At molecular level, PT converts to intermediate ptaquiloside (APT) under alkaline conditions, which then goes on to alkylate DNA at N3 of adenine or N7 of guanine at 24 hours of exposure (Shahin et al., 1998). Influenced cells have the capacity to repair such damages in a short period of time; in contrast, a few of lesions lead to incorrect repairs which cause cancer. In addition, mutations in H-ras in $60 \%$ of rats were observed only after 10 weeks exposure to APT (Shahin et al., 1998). HRAS mostly activate an early event in the formation of tumors (Barbacid, 1987; Sukumar et al., 1995). Other genes that involve in this model are called p53 and neu (Gould, 1986;1995). Based on the cancer model of bracken, mutation in both of them is described at late events (Shahin et al., 1999). The neu oncogene also associates with mammary gland carcinoma in rat (Gould, 1986; 1995). The tumor suppressor gene, p53 contributes several human cancers (Gomes et al., 2012).

\section{Immunomodulatory Effects of Bracken-Fern}

Recent studies revealed that ptaquiloside suppresses IFN-Y production and NK cell-mediated cytotoxicity (Latorre et al., 2009). It was also verified that selenium supplementation prevents decrease in NK cytotoxicity which is caused by p. aquilinum (Latorre et al., 2011). In 2013 researchers showed that selenium prevents carcinogenic effects caused by immunosuppressive effects of bracken fern (Latorre et al., 2013). Furthermore, ptaquiloside involved in bracken may also promote carcinogenicity by decreasing immune supervision against lately arising tumors (Gil da Costa et al., 2012). In fact, the immunosuppressive effects of bracken may help carcinogenicity indirectly due to disorder of NK cell activity (Nakahara et al., 2013).

\section{Possible Toxic Agents in Bracken}

Studies have shown that many bracken constituents have low cytotoxic effects. Therefore, they are not directly involved in acute fern poisoning. The International Agency of Research into Cancer (IARC) reported that, there is enough evidence for carcinogenicity of bracken in animals (IARC, 1987). Although in human, the results are the same but insufficient for proving (IRAC, 1985). Chemical constituents of bracken are very varied and they depend on habitat (Chen et al., 2008).

Ptaquiloside is a potent toxin found in ferns. It was first isolated in 1983. In fact, the detection of ptaquiloside was a landmark in bracken research (Yamada et al., 2007). Fortunately, Methods for quantifying ptaquiloside in bracken have been developed (Bonadies et al., 2004; Jensen et al., 2008; Bonadies et al., 2011).Unlike rats treated with low PT content, Bracken fern containing high content of PT leads to many tumors in ileum and urinary bladder among treated rats. (Smith et al., 1988). PT has been known as a strong carcinogen. In addition, it was described to be responsible for the biological effects of bracken, such as acute bracken poisoning, bright blindness in sheep, mutagenicity, clastogenic effects and genotoxicity (Yamada et al., 2007). Recently, intraperitoneal ptaquiloside administration to CD-1 mice resulted in high level of urinary bladder dysplasia and a B-cell lymphoproliferative malignancy (Gill da Costa et al., 2011). PT should be considered highly as a carcinogenic compound for human. PT can be easily transmitted from milk to human; therefore, it is necessary to be cautious about cattle grazing (Wilson et al., 1998). Hirono's group also showed that using PT via oral route induces thrombocytopenia, myeloid aplasia, and neutropenia in a calf typical of the acute haemorrhagic syndrome (Hirono et al., 1984).

Cyanogenic glycosides are enzymatically hydrolysed by B-glucosidase, thereby hydrocyanic acid ( $\mathrm{HCN})$ and glucose are released. (Gil da Costa et al., 2012). All bracken varieties are not cyanogenic and prunasin is the only reported one which is thought to act as a feeding deterrent against insects and herbivore mammals, due to its acrid taste. (Alonso-Amelot and Oliveros-Bastidas, 2005). Prunasin is abundant in young crosiers (OliverosBastidas and Alonso-Amelot, 2010).

Shikimic acid has not shown many evidences for carcinogenicity in animals studies and there is not sufficient evidence for Its carcinogenicity in human. Although it is unlikely to be a carcinogenic starting agent, it might act as a carcinogenic stimulating factor in bracken fern (Jones et al., 1983).

Thiaminase is a compound found in all parts of bracken. It leads to destruction of thiamin and subsequent health problems like beriberi in animals fed bracken fern. Plant Thiamine reaches to its maximum amount in summer which will remain even after plant withered state. After bracken collection and storage, thiamin is remained and can increase toxic effects (Barr and Reagor, 2001).

Quercetin is dose-dependent in vitro (Rahman et al., 


\section{Motahhareh Tourchi-Roudsari}

1992), but not in vivo (Utesch et al., 2008). Although some scientists suggested that quercetin-induced mutations might contribute to the appearance of a malignant phenotype in vivo (Borzacchiello and Roperto, 2008), it is not seem to play a role in carcinogenicity of bracken fern (Van der Hoeven, 1985). Indeed, Qu has pro-apoptotic effect that leads to cell damage and cytotoxicity. These effects of Qu may be resulted from various pathways (Gibellini et al., 2011). For example, the ability of Qu to induce apoptosis through mitochondrial pathway has been confirmed in U937 cell line (Ferraresi et al., 2005; Lugli et al., 2005). Even antiproliferative effects of Qu could be related to the ability of $\mathrm{Qu}$ for binding to tubulin which stimulates cellular microtubules depolymerization (Gupta and Panda, 2002). Furthermore, studies show that $\mathrm{Qu}$ as a pro-apoptotic flavonoid acts specifically on tumor cell lines rather than normal ones. The studies show that $\mathrm{Qu}$ is eliminated due to limitation of absorption completely with metabolism in the intestinal, decomposition completely, and its toxic effects (Staviric, 1994). So, it seems that Qu exists only in vitro.

Pterosin is widely in ferns (Hayashi et al., 1972; Fukuoka et al., 1978; Ng KE and MeMorris, 1984). There are 20 kinds of pterosins and pterosides in bracken (Saito et al., 1989). Although some pterosins induce in vitro cytotoxicity in cancer cells, but they have no genotoxic effect or no bracken cytotoxicity for animals (Chen et al., 2008). Several pterosins showed cytotoxic effects on ciliate. Experimental studies on rats showed that bracken boiling-water extract of induced intestinal and bladder tumors (Hirono et al., 1978; Santos et al., 1987), maternal toxicity, embryotoxicity and minor abnormalities in offspring (Gerenutti et al., 1992; Freitas et al., 2002).

Freshly, there was a study about constituents of bracken grown up in Yannan of China. 5-Hydroxypyrrolidin-2-one, Shikimic acid and glycerol 1-stearate were extracted from young fronds of the plant for the first time (Chen et al., 2008).

\section{Chemistry of PT Reactions}

PT is unstable under acidic and alkaline conditions. It is rapidly hydrolyzed with water and produces Ptaqilosin with the lack of sugar units. It rapidly decomposes to Pterosin B in acidic conditions (Yoshihira et al., 1971; Fukuoka et al., 1978; Gomes et al., 2012) or it is converted to an unstable intermediate compound in a weak alkaline solution. This compound can activate a carcinogen called Dienone (APT) that acts as a powerful alkylating agent (Ojika et al., 1987). Dienone alkylate purin bases of DNA are naturally removed from DNA as alkylated parts. Then breaks occur in DNA structure and carcinogenicity begins (Radostits et al., 2000; Dawra and Sharma, 2001). (Figure 1)

\section{Bracken Fern Problems in Livestock}

During the periods of reduced food availability, domestic animals (herbivores and pigs) eat bracken easily and willingly, especially its tender young parts (shahin et al., 1999). The effects of bracken ingestion are diverse,

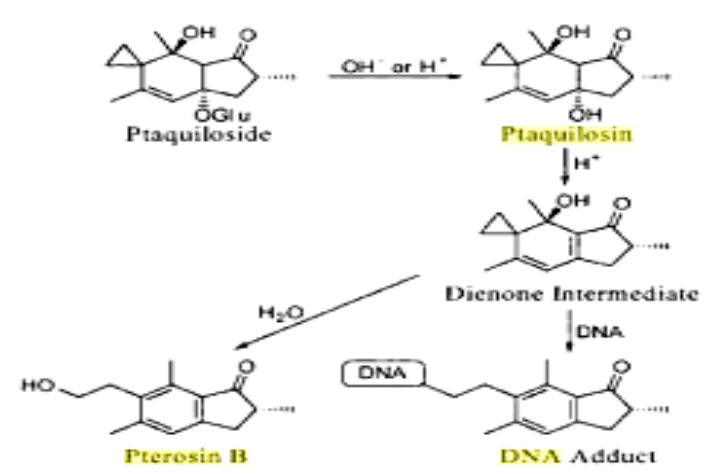

Figure 1. Proposed Scheme of Ptaquiloside Reaction Pathway (Shahin et al., 1999)

depending on the animal species and the ingested dose(s) (Vetter, 2010).

Thiamine deficiency in monogastrics

In monogastric (single-stomach) animals, such as horses, toxicity is related to the enzyme thiaminase (Perez-Alenza et al., 2006; Vetter, 2009; Di Loria et al., 2012). In horses, thiaminase breaks into the necessary vitamin thiamine (B1), pyrimidine, and thiazole, which are inactivated in body (Knight and Walter, 2001). Thiamine is a crucial compound in metabolism that plays an important role in myelination of peripheral nerve system (SameckaCymerman et al., 2009). In the presence of thiaminase, blood thiamine levels in horses can reduce from a normal level $80-100 \mathrm{mg} / \mathrm{L}$ to $25-30 \mu \mathrm{g} / \mathrm{L}$ (Samecka-Cymerman et al., 2009).

\section{Acute toxicity with bracken}

It rarely occurs and there is low fatality. However, in some cases high numbers of incidence and mortality are observed (Radostits et al., 2000). Estimation the amount of plant toxicity is different in cows fed bracken. During 1 month, they probably show clinical signs and die (Humphreys, 1988).

\section{Acute hemorrhagic syndrome (loss of blood)}

Ptaquiloside is the major toxin which is responsible for bone marrow suppression and carcinogenic activities observed in ruminants. It is a lactone molecule discovered in highest concentrations in young growing parts of the plant (Perez-Alenza et al., 2006; Di Loria et al., 2012; Panter et al., 2011).

The acute hemorrhage and sudden death occur as a result of bone-marrow depression of subsequent thrombocytopenia (the condition of having a low platelet count) and increment trend to bleed (Samecka-Cymerman et al., 2009).

\section{Enzootic Hematuria in cattle}

It is a chronic and serious disease in cattle (PerezAlenza et al., 2006; Di Loria et al., 2012). Consuming $1-2 \mathrm{~kg}$ of bracken for 10-15 months by cows leads to Hematuria (Van Metre and Divers, 2002; Panter et al., 2007; Lucena et al., 2011). A recent report indicates the occurrence of a similar syndrome in buffaloes and sheep (Somvanshi, 2011; Dawra and Sharma, 2001; Radostits et al., 2000). Prevalence of disease is various in different 
regions. This disease occurs in both sexes. However mortality is higher in male animals due to obstruction of urinary tract by blood clots (Dawra and Sharma, 2001). The hematuria forms varied tumors, especially hemangioma in the bladder wall. PT in bracken has been known as a toxic compound that causes bovine enzootic haematuria. It also induces bladder tumours in laboratory animals (Hirono et al., 1987; Radostits et al., 2000; Dawra and Sharma, 2001). The oncogenesis of PTinduced bladder has not been investigated completely, but a number of experiments have demonstrated its molecular and morphological features (Carvalho et al., 2007; Guidi et al., 2008; Corteggio et al., 2010; 2011; Pires et al., 2010; Roperto et al., 2010).

\section{Blindness in sheep}

Long-term consumption of bracken by sheeps leads to the formation of nonfatal diseases such as "Progressive retinal degeneration" or bright blindness (PRD). (Somvanshi and Ravisankar, 2004; Perez-Alenza et al., 2006; Di Loria et al., 2012)

\section{Neoplasia in gastrointestinal tract}

Neoplasia in gastrointestinal tract including jaw and liver is observed in adult sheep feeding on bracken fern. The reports show that there is no relationship between tumor formation and the presence of HPV. There is also high incidence of colon and bladder tumors in cattle fed in lands covered with bracken (Angus and Sharman, 1991; Radostits et al., 2000).

\section{Possible Pathways of Bracken Exposure in Humans}

\section{Food}

Fern leaves have edible consumption in Japan, Brazil and Canada (Hirono, 1993; Hojo-Souza et al., 2010). Studies have revealed the dependence between bracken consumption and the stomach and esophagus cancer in human (Wilson et al., 1998). Daily intake of bracken in japan increases the risk of oesophageal cancer about 2.1fold in men and 3.7-fold in women (Kamon and Hirayama, 1975; Hirayama, 1979). Possible risk of consumption of animal meat that fed bracken doesn't have been studied and is still unknown (Wilson et al., 1998).

\section{Milk}

Risk of digestive tract cancer exposed to bracken has been studied in South and Central America (VillalobosSalazar, 1985; Alonso-Amelot and Avendano, 2001). Carcinogenic compounds have been secreted from milk and urine of livestock that consume bracken fern. Moreover, it is proved that it can cause cancer in laboratory animals. The studies show that even the activity of carcinogenic compounds in the milk of animals fed on bracken is more than bracken compounds (Alonso-Amelot et al., 1996). Recently, Ptaquiloside has been detected in meat and milk from cattle consuming bracken (Bonadies et al., 2010; Fletcher et al., 2011). Pasteurisation was found to decrease ptaquiloside concentrations in milk by $50 \%$ and a $75 \%$ decrease by boiling (Villalobos-Salazar et al.,
2000). Therefore, boiling the milk before drinking it may be a helpful recommendation for people who live in rural areas suspected of being exposed to considerable amounts of Ptaquiloside (Gil da Costa et al., 2012)

\section{Water}

Water contamination may also occur. Ptaquiloside leaching from fronds exposed to rain may subsequently contaminate soil and groundwater (Ayala-Luis et al., 2006; Engel et al., 2007; Ovesen et al., 2008; Jensen et al., 2008). There is no evidence to prove that water contamination with bracken fern can cause disease in human; nonetheless, a number of toxic compounds in fern are soluble in water and probably can be entered into water tanks (Evans et al., 1984).

\section{Inhalation and ingestion of spores}

Spores are proved to be one of the ways of ptaquiloside transfer from bracken to humans (Rasmussen et al., 2013). Therefore, this finding is very probable to describe the toxicity of bracken spores for laboratory mice and human cell lines (Rasmussen et al., 2013). Lymphocytic leukaemia has been reported in mice fed bracken spores, and bracken spores have proven to have genotoxic effects for human cell lines, including gastric cells (Siman et al., 2000; Gomes et al., 2012). The fern spores have been identified as a carcinogenic agent in mice (Evans, 1979). Inhalation and ingestion of spores can be carcinogenic in humans (Wilson et al., 1998). The study is only about direct ingestion of spores not the effects of animal exposure to airborne spores (Wilson et al., 1998). The research showed that, spores administered by gavage produce DNA adducts in mice (Povey et al., 1996). The significance of these results requires further examinations.

\section{Skin}

There is no finding about the effects of ferns on humans and animals via direct contact with skin; however, this pathway would seem an unlikely cause of disease (Wilson et al., 1998).

\section{Studies on Human Health}

Most speculations about harmful effects of bracken on human health is based on its effects on animals, but it is not possible to reach a conclusion for human based on experiments on model animals; However, researchers conclude that there is a direct connection between bracken consumption and stomach cancer in men and women and esophageal cancer in men only (Wilson et al., 1998). The risk of esophageal cancer that associates with the consumption of bracken is estimated to be about 2.1-fold in men and 3.7-fold in women (Kamon and Hirayama, 1975). The highest incidence of stomach cancer was found in those who have spent their childhood in covered lands such as Gwynedd region (Galpin et al., 1986; Galpin et al., 1990). The fact that consumption of bracken and stomach and esophagus cancer are not related to each other was known substantially in Brazil (Marliere et al., 1995). The association between ferns and cancer in has been investigated in England and Wales (Wells and McNally, 
1989). Villalobos-Salazar and co-workers compared incidence rates of stomach cancer among people who were born in bracken infested and bracken free areas in Costa Rica considering their age (Campo et al., 1990). Brackeninfested and bracken-free were determined according to height above sea level, which is a confirmed method in previous studies. It was reported that the number of gastric and esophageal cancer victims among women and all people who were born in bracken infested areas were at least twice than those who were born in bracken free areas (Wilson et al., 1998).

High daily consumptions of pickles, edible wild plants, especially bracken crosiers, were significantly related to increase of pancreatic cancer risk, particularly in men, who had a relative risk of 2.98 (95\% CI=1.46-6.07) (Ramwell et al., 2010).

In a study of 783 patients with stomach cancer and 1566 hospital controls in Hiroshima and Miyagi, a higher risk of stomach cancer was known in Japanese farmers and totally among Japanese population, not other jobs or even Hawaiian-Japanese (Haenszel et al., 1976). An association was known between bracken consumption and stomach cancer. Japanese higher consumption rates of Bracken accounts for mentioned population differences (Ramwell et al., 2010). The association between dietary intake of bracken and esophagus cancer was investigated in 98 cancer patients and 476 control cases aged 60 or older in Japan.

The relative risk of cancer was $2.68(95 \% \mathrm{CI}=1.38$ $5.21)$ in those who eat bracken every day and 1.53 (95\% CI $=0.90-2.62)$ in those who ate bracken occasionally, as compared with those who ate bracken rarely or not at all ( $\chi^{2}$ trend $\left.=8.04, p=0.004\right)$ (Ramwell et al., 2010).

\section{Control of Bracken}

According to the plant's rhizomatous rooting system and its ability for producing a large amount of spores, spread and control of bracken fern can be difficult (Bebbington and Wright, 2009). Growth can be controlled by regular cutting of mature plant or by deep plowing over time (Burrows and Tyrl., 2001). Moreover, herbicide may be an effective control if teamed with close cutting to encourage vegetative growth before a treatment is applied (Burrows and Tyrl, 2001).

\section{Conclusion}

The toxicity of bracken fern and its constituents, mainly ptaquiloside, have been investigated in studies of farm and laboratory animals and in human epidemiological studies. Bracken fern, a widespread plant, is toxic for many animal species. It can affect a high percentage of animals and many body systems. The observations show that most of the people who work or play among bracken ferns, are at risk for cancer, particularly in spring; besides, people who eat bracken as vegetable or drink milk from cows that are fed bracken are endangered. Bracken fern extract is a potent source of anticancer compounds. It can be utilized pharmaceutically. Further studies, are required to clarify the biological relevance of this response.

\section{Acknowledgements}

The author would like to thank Dr. Mohammad Reza Aslani for his helpful discussions. I am also grateful to Maryam Dehghan Hesami for her paper editing.

\section{References}

Almeida Santos MdF, Dorea JG, Luna H (2006). Bracken-fern extracts can be clastogenic or aneugenic depending on the tissue cell assay. Food Chem Toxicol. 44, 1845-8.

Alonso-Amelot ME, Avedano M (2001). Possible association between gastric cancer and bracken fern in Venezuela: an epidemiologic study. Int J Cancer, 91, 252-9.

Alonso-Amelot ME, Avendano M (2002). Human carcinogenesis and bracken fern: a review of the evidence. Curr Med Chem, 9, 675-86.

Alonso-Amelot ME, Oliveros-Bastidas A (2005). Kinetics of the natural evolution of hydrogen cyanide in plants in neotropical pteridium arachnoideum and its ecological significance. J Chem Ecol, 31, 315-31.

Alonso-Amelot ME, Castillo U, Smith BL, et al (1996). Bracken ptaquiloside in milk. Nature, 382, 587-8.

Angus KW , Sharman GAM (1991). Plant poisoning. IN: Diseases of Sheep, $2^{\text {nd }}$ edition, ed by W. B. Martin and I. D. aitken, blackwell scientific publications, London.

Ayla-Luis KB, Hansen PB, Rasmussen LH, et al (2006). Kinetics of Ptaquiloside Hydrolysis in aqueous solution. Environ Toxical Chem, 25, 2623-9.

Barbacid M (1987). Ras genes. Annu Rev Biochem, 56, 779-827.

Barr AC, Reagor JC (2001). Toxic plants, what the horse practioner need to know. Vet Clin North Am. 17, 529-46.

Bebbington A, wright B (2009). Bracken-fern poisoning in horses. ministry of agriculture, food and rural affairs/ontario. order no. 09-049. AGDEX 663/460.

Bonadies F, Berardi G, Nicoletti R, et al (2010). A new, very sensitive method of assessment of ptaquiloside, the major bracken carcinogen in the milk of farm animals. Food Chem, 124, 660-5.

Bonadies F, Borzacchiello G, Dezzi S, et al (2004). Mass spectrometric analysis of ptaquiloside, the toxic sesquiterpene from bracken fern. Rapid Communications in Mass Spectrometry, 18, 825-82.

Borzacchiello G, Roperto F (2008). Bovine papillomaviruses, papillomas and cancer in cattle. Vet Res, $\mathbf{8}, 45$.

Burrows GE, Tyrl RJ (2001). Toxic plants of North America. ames, Iowa: Iowa State Press, 415-22.

Campo MS, McCaffery RE, Doherty I, et al (1990). The Harvey ras 1 gene is activated in papilloma-associated carcinomas of the alimentary tract in cattle. Oncogene, 5, 303-8.

Campos-da-Paz M, Pereira LO, Bicalho LS, et al (2008). Interaction of bracken-fern extract with vitamin $\mathrm{C}$ in human submandibular gland and oral epithelium cell lines. Mutat Res, 652, 158-63.

Carvalho T, Pinto C, Peleteiro MC (2006). Urinary bladder lesions in bovine enzootic haematuria. J Comp Pathol, 134, 336-46.

Carvalho T, Elias AP, Nunes T, et al (2007). Chemo-angiogenic profile of bovine urinary bladder tumors distinguishes urothelial carcinomas from hemangiossarcoma vet. Immunol Immunopathol, 121, 344-58.

Castillo UF, Ojika M, Alonso-Amelot M, et al (1998). Ptaquiloside Z, a new toxic unstable sesquiterpene glucoside from the neotropical bracken fern Pteridium aquilinum var. caudatum. Bioorg Med Chem, 6, 2229-33.

Cheeke PR (1989). Carcinogenic Bracken Glycosides. In: Cheek, PR. Toxicants of plant origon. Florida, 239-51. 
Chen Y, Zhao Y, Hu Y, et al (2008). Isolation of 5-hydroxypyrrolidin-2-one and other constituents from the young fronds of Pteridium aquilinum. J Nat Med, 62, 358-9.

Corteggio A, Urraro C, Roperto S, et al (2010). Phosphatidylinositol-3-kinase-AKT pathway, phosphorJUN and phosphor-JNK expression in spontaneously arising bovine urinary bladder tumours. J Comp Pathol, 143, 173-8.

Corteggio A, Di Geronimo O, Roperto S, et al (2011). Bovine papillomavirus E7 oncoprotein binds to p600 in naturally occurring equine sarcoids. J Gen Virol, 92, 378-82.

COT (2008)- Committee on the toxicity of chemicals in food, consumer products and the environment, COT statement on the risk to consumer of eating foods derived from animals that have eaten bracken, food standards agency, London.

Dawra RK, Sharma OP (2001). Enzootic bovin haematuriapast, present and future. Vet Bull, 71, 1-27.

Di Loria A, Piantedosi D, Cortese L, et al (2012). Clotting profile in cattle showing chronic enzootic haematuria (CEH) and bladder neoplasms. Res Vet Sci, 93, 331-5.

Engle PL, Black MM, Behrman JR, et al (2007). Strategies to avoid the loss of developmental potential in more than 200 million children in the developing world. The Lancet, $\mathbf{3 6 9}$, 229-42.

Evans IA (1968). The radiomimetic nature of bracken toxin. Cancer Res, 28, 2252-61.

Evans IA (1979). Bracken carcinogenicity. Res Vet Sci, 26, $339-48$.

Evans IA, Al-Samarrai, AM, Smith RM (1984). Bracken toxicology: identification of some water soluble compounds from crozier and rhizome. Res Vet Sci, 37, 261-5.

Evans WC, Patel Y, Kooh y (1982). Acute bracken poisoning in homogastric and ruminant animals, Proc-R Soc Edinburgh. 81, 29-64.

Evans IA, Mason J (1965). Carcinogenic activity of bracken. Nature, 208, 913-4.

Ferraresi R, Troiano L, Roat E, et al (2005). Essential requirement of reduced glutathione (GSH) for the anti-oxidant effect of the flavonoid quercetin. Free Radical Res, 39, 1249-58.

Fletcher MT, Reichmann KG, Brock IJ, et al (2011). Residue potential of norsesquiterpene glycosides in tissues of cattle fed Austral bracken (Pteridium aquilinum). J Agric Food Chem, 59, 8518-23.

Freitas RN, Brasileiro-Filho G, Silva Meet al (2002). Bracken fern-induced malignant tumors in rats: absence of mutations in p53, H-ras and K-ras and no microsatellite instability. Mutat Res, 499, 189-96.

Freitas RN, O'Connor PJ, Prakash AS, et al (2001). Bracken (Pteridium aquilinum)-induced DNA adducts in mouse tissues are different from the adduct induced by the activated form of the Bracken carcinogen ptaquiloside. Biochem Biophys Res Commun, 281, 589-94.

Fukuoka M, Kuroyanagi M, Yoshihira K, et al (1978). Chemical and toxicological studies on bracken fern Pteridium aquilinum var. latiusculum: II. Structure of pterosins, sesquiterpenes having 1-indanone skeleton. Chem Pharm Bull, 26, 2365-85.

Galpin OP, Smith RMM (1986). Bracken, stomach cancer and water supplies: is there a link? In: Smith RT, Taylor JA, eds. Bracken: Ecology, Land Use and Control Technology; 1985 July 1 - July 5; Leeds, Lancs: The Parthenon Publishing Group Limited: 147-59.

Galpin OP, Whitaker CJ, Whitaker R, et al (1990). Gastric cancer in Gwynedd. Possible links with bracken. Br J Cancer, 61, 737-40.

Gerenutti M, Spinosa Hde, Bernardi MM (1992). Effects of bracken fern (Pteridium aquilinum L Kuhn) feeding during the development of female rats and their offspring. Vet Hum
Toxicol, 34, 307-10.

Gibellini L, Pinti M, Nasi M, et al (2011). Quercetin and cancer chemoprevention. Evid Based Complement Alternat Med, 2011, 591356.

Gil da Costa RM, Bastos MMSM, Oliveira PA, et al (2011). Isolation of carcinogenic and cyanogenic bracken (Pteridium aquilinum) constituents from mainland Portugal specimens, in: Proceedings of the $9^{\text {th }}$ European Congress of Toxicological Pathology, Uppsala, Sweden, 233.

Gil da Costa R, Coelho P, Sousa R, et al (2012). Multiple genotoxic activities of ptaquiloside in human lymphocytes: Aneugenesis, clastogenesis and induction of sister chromatid exchange. Mutation Res, 747, 77-81.

Gould MN (1986). In heritance and site of expression of genes controlling susceptibility to mammary cancer in an inbred rat model. Cancer Res, 46, 1199-202.

Gould MN (1995). Animal models for the study of genetic susceptibility to cancer. Cancer Biol Med, 4, 99-110.

Gomes J., Magalhaes A, Michel V, et al (2012). Pteridium aquilinum and its ptaquiloside toxin induce DNA damage Response in gastric epithelial cells, a link with gastric carcinogenesis. Toxicol Sci, 126, 60-71.

Guidi L, Jackson GA, Stemmann L, et al (2008). Relationship between particle size distribution and flux in the mesopelagic zone. Deep-Sea Res, 55, 1364-74.

Gupta K, Panda D (2002). Perturbation of microtubule polymerization by quercetin through tubulin binding: a novel mechanism of its antiproliferative activity. Biochemistry, 41, 13029-38.

Haenszel W, Kurihara M, Locke FB, et al (1976). Stomach cancer in Japan. J Natl Cancer Inst, 56, 252-9.

Hayashi Y, Nishizawa M, Harita S, et al (1972). Structures and syntheses of Hypolepin A, B and C, sesquiterpenes from Hypolepis punctata METT. Chem Lett, 375-8

Hirayama T (1979). Diet and cancer. Nutr Cancer, 1, 67-81.

Hirono I (1993). Edible plants containing naturally occurring carcinogens in Japan. Jpn J Cancer Res, 84, 997-1006.

Hirono I, Hosaka S, Kuhara K (1982). Enhancement by bracken of induction of tumors of the upper alimentary tract by N-propyl-N-nitrosourethan. Br J Cancer, 46, 423.

Hirono I, Shibuya C, Fushimi K, et al (1970). Studies on carcinogenic properties of bracken. Pteridium aquilinum, $J$ Natl Cancer Inst, 45, 179.

Hirono I, Shibuya C, Shimizu M, et al (1972). Carcinogenic activity of processed bracken used as human food. J Natl Cancer Inst, 48, 1245.

Hirono I, Ushimaru Y, Kato K, et al (1978). Carcinogenicity of boiling water extract of bracken. Pteridium aquilinum Gann, 69, 383-8.

Hirono I, Yamada K, Niwa H, et al (1984). Separation of carcinogenic fraction of bracken fern. Cancer Lett, 21, 239-46.

Hirono I, Ogino H, Fujimoto M, et al (1987). Induction of tumors in ACI rats given a diet containing ptaquiloside, a bracken carcinogen. J Natl Cancer Inst, 79, 1143-9.

Hojo-Souza NS, Carneiro CM, Santos RC (2010). Pteridium aquilinum: what we know and what is yet to be learnt. Biosci $J, 26,798-808$.

Humphreys DJ (1988). Veterinary Toxicology. $3^{\text {rd }}$ ed, Baillier Tindall. London.

IRAC (Interagency Research Animal Committee). The U.S. government principles for the utilization and care of vertebrate animals used in testing, research, and training. federal register. Vol. 50, No. 97 (May 20, 1985) Office of Science and Technology Policy; 1985. [Accessed January 30, 2008].

International Agency for Research into Cancer (IARC) (1987). 
Bracken Fern (Group 2B). IARC Monogr Eval Carcinog Risk Chem Hum, 135-6.

Jensen PH, Jacobsen OS, Hansen HCB, et al (2008). Quantification of ptaquiloside and pterosin B in soil and groundwater using liquid chromatography-tandem mass spectrometry (LC-MS/MS). J Agric Food Chem, 56, 984854.

Jones RS, Ali M, Ioannides C, et al (1983). The mutagenic and cell transforming properties of shikimic acid and some of its bacterial and mammalian metabolites. Toxicol Lett, 19, 43-50.

Kamon S, Hirayama T (1975). Epidemiology of cancer of the oesophagus in Mie, Nara and Wakayama prefectures with special reference to the role of bracken fern, Proc Jpn Cancer Assoc, 34, 211.

Khoshravesh R, Akhani H, Eskandari M, et al (2009). Fern and Fern allies of Iran. Rostaniha, 10, 1-130.

Knight AP, Walter RG (2001). A Guide to Plant Poisoning of Animals in North America. Teton New Media, Jackson, WY.

Kushida T, Uesugi M, Sugiura Y, et al (1994). DNA damage by ptaquiloside, a potent bracken carcinogen: Detection of selective strand breaks and identification of DNA cleavage products. J Am Chem Soc, 116, 479-86.

Latorre AO, Furlan MS, Sakai M, et al (2009). Immunomodulatory effects of Pteridium aquilinum on natural killer cell activity and on select aspects of the cellular immune response of mice. J Immunotoxicol, 6, 104-114.

Latorre AO, Caniceiro BD, Wysoki Jr HL, et al (2011). Selenium reverses Pteridium aquilinum-induced immunotoxic effects, Food Chem Toxicol, 49, 464-470.

Latorre AO, Caniceiro BD, Fukumasu H, et al (2013). Ptaquiloside reduces NK cell activities by enhancing metallothionein expression, which is prevented by selenium. Toxicology, 304, 100-8.

Li HY, Wang LC, Tang WB (2008). Analysis and contrast on the nutrition components among wild and cultivated Pteridium aquilinum var. latiuscu-lum and common vegetables[J]. Journal of Anhui Agricultural Sciences, 36, 5868-9

Lucena RB, Rissi DR, Kommers GD, et al (2011). A retrospective study of 586 tumours in Brazilian cattle. J Comp Pathol, 145, 20-4.

Lugli E, Troiano L, Ferraresi R, et al (2005). Characterization of cells with different mitochondria membrane potential during apoptosis, cytometry part A. 68, 28-35.

Marliere CA, Santos RC, Galvao MAM, et al (1995). Gastric and oesophageal cancer related to bracken, Ingestion: a case control study from ouro petro, minas gerais, Brazil, presented at Bracken: an environmental issue, University of Wales, Aberystwyth.

Marrs R.H, Watt A.S (2006). Biological flora of the British Isles: Pteridium aquilinum (L.) kuhh. J Ecol, 94, 1272-321.

Nakahara SBR, Sanches DS, Caniceiro BD, et al (2013). Effects of selenium on Pteridium aquilinum and urethane-induced lung carcinogenesis. Immunopharmacol Immunotoxicol, 35, 605-14.

$\mathrm{Ng} \mathrm{KE}$, McMorris T (1984). An efficient synthesis of pterosin $\mathrm{C}$ and other pterosins. Can J Chem, 62, 1945-53.

Ojika M, Wakamatsu K, Niwa H, et al (1987). Ptaquiloside a potent carcinogen isolated from bracken fern Pteridium aquilinum var. latiusculum: structure elucidation based on chemical and spectral evidence and reaction with amino acids, nucleosides and nucleotides, Tetrahedron, 43, 526174.

Oliveros-Bastidas AJ, Alonso-Amelot ME (2010). Cyanogenic polymorphism in brackens, Pteridium arachnoideum and P. caudatum, from the northern Andes. Quimica Nova, 33, 1520-24.
Ovesen RG, Rasmussen LH, Hansen HCB (2008). Degradation kinetics of ptaquiloside in soil and soil solution. Environmental Toxicol Chem, 27, 252-9.

Panter KE, Gardner DR, Lee ST, et al (2007). Important poisonous plants of the United States, In: R. C. Gupta (Ed.) Veterinary Toxicology: basic and clinical principles, Academic Press, New York, USA, 859-61.

Panter KE, Ralphs MH, Pfister JA, et al (2011). Plants poisonous to livestock in the western states. United States Department of Agriculture, Agricultural Research Service. Agricultural Information Bulletin 415.

Pamukcu AM , Price JM (1969). Induction of intestinal and urinary bladder cancer in rats by feeding bracken fern (Pteris aquiline). J Natl Cancer Inst, 43, 275.

Pereira LO, Bicalho LS, Campos-da-paz Lopes M, et al (2009). DNA damage and apotosis induced by Pteridium aquilinum aqueos extract in the oral cell lines HSG and OSCC-3. J Oral Pathol Med, 38, 441-7.

Perez-Alenza MD, Blanco J, Sardon D, et al (2006). Clinicopathological findings in cattle exposed to chronic bracken fern toxicity. New Zealand Vet J, 54, 185-92.

Petitjean A, Mathe E, Kato S, et al (2007). Impact of mutant p53 functional properties on TP53 mutation patterns and tumor phenotype: Lessons from recent developments in the IARC TP53 database. Hum Mutat, 28, 622-9.

Pires A, Paxton H, Quintino V, et al (2010). Diopatra (Annelida: Onuphidae) diversity in European waters with the description of Diopatra micrura, new species. Zootaxa, 2395, 17-33.

Potter DM, Baird MS (2000). Carcinogenic effects of ptaquiloside in bracken fern and related compounds. $\mathrm{Br} \mathrm{J}$ Cancer, 83, 914-20.

Povirk LF (2006). Biochemical mechanisms of chromosomal translocations resulting from DNA double-strand breaks. DNA Repair (Amst), 5, 1199-212.

Povey AC, Potter D, O'Connor PJ (1996). Post-labelling analysis of DNA adducts formed in the upper gastrointestinal tissue of mice fed bracken extract or bracken spores. Br J Cancer, 74, 1342-8.

Radostits OM, Gay CC, Blood DC, et al (2000). Veterinary Medicine. 9th edition, Sounders Company, London.

Rahman A, Fazal F, Greensill J, et al (1992). Strand scission in DNA induced by dietary flavonoids: role of cu (I) and oxygen free radicals and biological consequences of scission. Mole Cell Biochem, 111, 3-9.

Ramwell CT, van Beinum W, Rowbothan A, et al (2010). Ptaquiloside and other bracken toxins: a preliminary risk assessment. final report. sand hutton: the food and environmental research agency, UK.

Rasmussen LH, Jensen LS, Hansen H (2003). Distribution of the carcinogenic terpene ptaquiloside in bracken fronds, rhizomes (Pteridium aquilinum), and litter in Denmark. $J$ Chem Ecol, 29, 771-8.

Rasmussen LH, Schmidt B, Sheffield E (2013). Ptaquiloside in bracken spores from Britain. Chemosphere, 90, 2539-41.

Roperto S, De Tullio R, Raso C, et al (2010). Calpain 3 is expressed in a proteolitically active from in papillomavirusassociated urothelial tumors of the urinary bladder in cattle. PloS One, 22, 10299.

Saito K, Nagao T, Matoba M, et al (1989). Chemical assay of ptaquiloside, the carcinogen of Pteridium aquilinum, and the distribution of related compounds in the pteridaceae. Phytochemistry, 28, 1605-11.

Samecka-Cymerman A, Garbiec K, Kolon K, et al (2009). Factor analysis of the elemental composition of Pteridium aqulinum from serpentine and granite soils as a tool in the classification of relations between this composition and the type of parent rock in the Sleza Massif in Lower Silesia, 
Poland Environ Geol, 58, 509-14.

Santos RC, Brasileiro-Filho G, Hojo ES (1987). Induction of tumors in rats by bracken fern (Pteridium aquilinum) from Ouro Preto (Minas Gerais, Brazil). Braz J Med Biol Re, 20, 73-77.

Shahin M, Smith BL, Prakash AS (1999). Bracken carcinogens in the human diet. Mutat Res, 443, 69-79.

Shahin M, Moore MR, Smith BL, et al (1998). Acute and chronic toxicity induced by activated ptaquiloside in rats: comparison of pathogenesis due to oral and intravenous administration, in: Garland T, Barr AC (Eds.). Toxic Plant and Other Natural Toxicants, CAB International, Wallingford, UK, 255-259

Siman SE, Povey AC, Ward TH, et al (2000). Fern spore extracts can damage DNA. Br Cancer, 83, 69-73.

Smith BL, Embling PP,Agnew MP, et al (1988). Carcinogenicity of bracken fern (Pteridium esculentum) in New Zealand. $N$ $Z$ Vet J, 36, 56-8.

Smith BL, Seawright AA, Ng J, et al (1944). Concern-tration of Ptaquiloside, a major carcinogen in bracken fern (Pteridium spp), from eastern Australia and from a cultivated worldwide collection held in Sydney, Australia. Natural Toxins, 2, 347-53.

Somvanshi R, Ravisankar R (2004). Resent advances in bracken fern toxic research. Natural Product Radiance, 3, 304-8.

Somvanshi R (2011). Papillomatosis in buffaloes: a less-known disease, Transbound Emerg Dis, 58, 327-32.

Stavric B (1994). Quercetin in our diet: from potent mutagen to probable anticarcinogen. Clin Biochem, 27, 245-8.

Sukumar S, Mckenzie K, Chen Y (1995). Animal models for breast cancer. Mutation Research/Fundamental and Molecular Mechanisms of Mutagenesis, 333, 37-44

Talylor JA (1990). The bracken problem: a global perspective. AIAS Occas Publ, 40, 3-19.

Tourchi RM, Bahrami AR, Dehghani H, et al (2012). Brackenfern extracts induce cell cycle arrest and apoptosis in certain cancer cell lines. Asian Pac J Cancer Prev, 13, 6047-53.

Utesch D, Feige K, Dasenbrock J, et al (2008). Evaluation of the potential in vivo genotoxicity of quercetin. Mutatation Res, 654, 38-44.

Van der Hoeven JC (1985). Occurrence and detection of natural mutagens and modifying factors in food products. Princess Takamatsu Symp, 16, 119-137.

Van Metre DC, Divers TJ (2002). Enzootic hematuria. In: Large Animal Interna Medicine, ed by B. P. Smith, 2nd edition, Mosbey Company, Philadelphia.

Vetter J (2009). A biological hazard of our age: bracken fern [Pteridium aquilinum (L.) Kuhn]--a review. Acta Veterinaria Hungarica, 57, 183-96.

Vetter J (2010). Toxicological medicinal aspects of the most frequent fern species, Pteridium aquilinum (L.) Kuhn, in: A. kumar, H. Fernandez, M.A. Revilla (Eds.), Working with Ferns: Issues and Applications, Springer, New York, 361-375.

Villalobos-Salazar, J (1985). Carcinogenicidad del Pteridium aquilinum y alta incidentia del cancer gastrico en costa rica. Revista Costa Rica Ciencies Medicine, 6, 131-9.

Villalobos-Salazar J, Hernandez H, Meneses A, et al (2000). Factors which may affect ptaquiloside levels in milk: effects of altitude, bracken fern growth stage, and milk processing. In: Taylor, J.A., Smith, R.T. (Eds.). Bracken fern: Toxicity, Biology and Control. Proceedings of the International Bracken Group Conference Manchester 1999, IBG, Aberystwyth, Wales, 68-74.

Wells AJ, McNally R (1989). Appraisal of the spatial association of bracken and cancer in England and Wales presented at bracken: An Environmental Issue.

Wang JL, Zhang J, Zhao BT, et al (2010). Carbohyrate Polymers,
80, 84-93.

Wang H, Wu S (2013). Preparation and antioxidant activity of Pteridium aquilinum-drived oligosaccharide. Biological Macromolecules, 61, 33-5.

Wilson D, Donaldson LJ, Sepai O (1998). should we be frightened of bracken? A review of the evidence. J Epidemiol Community Health, 52, 812-7.

Xia HT, Liu YF, Wang XY, et al (2010). Carbohydrate polymers, 80, 84-93.

Yamada K, Ojika M, Kigoshi H (2007). Ptaquiloside, the major toxin of bracken, and related terpene glycosides: chemistry, biology and ecology. Nat Prod Rep, 24, 798-813.

Yoshihira K, Fukuoka M, Kuroyanagi M, et al (1971). 1-indanone derivatives from bracken, Pteridium aquilinum var. latiusculum, Chem Pharm Bull, 19, 1491-5. 